\title{
Do the Eusebian Canon Tables Represent the Closure or the Opening of the Biblical Text? Considering the Case of Codex Fuldensis
}

\begin{abstract}
This chapter examines the implications the Eusebian canon tables had for the reading of the text of the gospels. Although Werner H. Kelber has suggested that the canon tables represent a milestone in the closing of the biblical text, I use the work of anthropologist Jack Goody to argue that, on the contrary, they are an information technology that opens up the text of the fourfold gospel to new kinds of analysis. This claim is then illustrated through a close examination of the modified canon tables apparatus Victor of Capua included along with the text of his Latin translation of Tatian's Diatessaron in the sixth-century Codex Fuldensis. Victor's modified version of the Eusebian apparatus made this manuscript the most paratextually complex book that had ever existed in the Latin tradition, allowing the reader to identify the portions of the four gospels Tatian was using for each line of his unum ex quattuor euangelium.
\end{abstract}

In the eighty years since the publication of Nordenfalk's seminal study, most of the scholarship on the Eusebian canon tables has followed his lead in focusing on the artistic aspects of the apparatus, though with some exceptions, most notably the studies of Elizabeth Mullins, Thomas O'Loughlin, Jeremiah Coogan, and the forthcoming edition by Martin Wallraff. ${ }^{1}$ Given the significance of the canon tables for art history and, more specifically, for the history of manuscript illustrations, this focus is entirely understandable. However, the emphasis on the artistic aspects of the canon tables tradition risks obscuring the fact that in other areas also it was just as innovative in the fourth century and just as generative for the later tradition. I have in mind here particularly the history of reading and the development of information technology, topics that I explore in depth in a recent monograph. ${ }^{2}$ In the present chapter I want to take up an issue that I touch upon in passing several times in the book but deserves further treatment, namely the implications

\footnotetext{
1 Mullins 2001 and 2014; O’Loughlin 2010; Coogan 2017; O’Loughlin 2017. See also McArthur 1965; Nordenfalk 1984; Grafton/Williams 2006, 194-199.

2 Crawford 2019.
}

that the Eusebian canon tables had for the actual reading of the text of the gospels. Put simply, how did reading a tetraevangelium equipped with canon tables differ from reading one that lacked the apparatus? What new possibilities were opened up, or, conversely, what modes of inquiry were discouraged or even prohibited that previ-

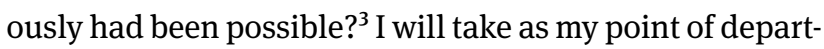
ure an article by the New Testament scholar Werner $\mathrm{H}$. Kelber, which represents one of the few comments upon this question, and will then turn to the work of the anthropologist Jack Goody, which provides greater theoretical underpinnings for a modified version of Kelber's position. In brief, Kelber argues that the canon tables are a major milestone in 'the history of the closure of biblical texts' in light of the 'artificiality' they assume with respect to oral performance. Goody's work on the social and cognitive impact of writing supports Kelber's argument about the 'artificiality' of the tables, but also suggests that far from merely closing the biblical text, the canon tables in fact open it up to new types of analysis thanks to the decontextualized mode of reading they encourage. In order to illustrate this claim, in the latter half of the paper I will examine one specific manuscript, the sixth-century Latin Diatessaron in Codex Fuldensis, which Victor of Capua fitted with a modified version of the Eusebian apparatus. The case of Codex Fuldensis highlights the way in which the canon tables encouraged a comparative analysis of texts, and even opened up questions that today would fall under the category of source criticism.

3 Compare the suggestive remarks from Martin Wallraff: 'Kurzum: so schlicht die Tabelle ist-sie setzt das neue Medium des Kodex voraus, und sie nutzt die damit gegebenen Möglichkeiten. Man stelle sich das Hin und Her bei einer Rolle vor, das Vor- und Zurückspulen zwischen Tabelle und Text: ganz unmöglich. Das neue Medium generiert ein neues Leseverhalten: nicht nur kontinuierliches, sondern auch konsultierendes Lesen' (Wallraff 2013, 32). For an analogous inquiry into the way in which ancient paratexts related to the mode of reading ancient texts, see Butler 2014. 


\section{Kelber's Closure}

Kelber's article is titled 'The History of the Closure of Biblical Texts' and in it he takes his cue from a 1992 essay by Walter Ong titled 'Technology Outside Us and Inside Us'. ${ }^{4}$ Kelber summarizes Ong's theoretical framework as consisting in the claim that 'Writing and print, as well as electronic devices [...] are technologies that produce something in the sensible world outside us but also affect the way our minds work'. ${ }^{5}$ This insight he then applies to the history of biblical texts, providing a grand, sweeping overview that begins with scribal culture in the Ancient Near East and ends with the advent of narrative criticism of biblical stories in the 1960s. Kelber's recounting of this history is unquestionably a narrative of decline and fall, in the tradition of Gibbon's history of Rome or of so many Protestant histories of Christianity's first millennium and a half. He states his thesis as follows: 'In macrohistorical perspectives, a trajectory is observable that runs from scribal multiformity, verbal polyvalency, and oral, memorial sensibilities toward an increasing chirographic control over the material surface of biblical texts, culminating in the autosemantic print authority of the Bible'. ${ }^{6}$ The evaluative judgment within this historical recounting is obvious. We begin in the Ancient Near East with an ideal scenario of 'multiformity', 'polyvalency', 'orality', 'anonymity', 'textual mobility', ${ }^{8}$ 'textual pluriformity', 'creative traditional[ism]', ${ }^{10}$ and 'equiprimordiality', ${ }^{11}$ all of which Kelber sums up in the term mouvance, denoting, in short, 'a living tradition in a process of persistent regeneration'. ${ }^{12}$ On the other hand, the lamentable state in which this story ends is one of 'control', 'authority', and 'stability', first with the creation of a 'canon' of texts and followed eventually by their exact mechanical reproduction enabled by the printing press. Such developments seemingly bring to an end the 'living tradition' by creating a closed textual universe that has no regard for the 'oral biosphere'. ${ }^{13}$

Placed roughly midway in the recounting of this history, the Eusebian canon tables do not fare well in Kel-

4 Ong 1992, 115-140.

5 Kelber 2010, 115.

6 Kelber 2010, 116.

7 Kelber 2010, 118.

8 Kelber 2010, 118.

9 Kelber 2010, 120.

10 Kelber 2010, 120.

11 Kelber 2010, 121.

12 Kelber 2010, 118. Kelber borrows the term from the work of Paul Zumthor on medieval French poetry.

13 Kelber 2010, 123. ber's telling. First, he recognizes the indebtedness of the Eusebian paratext to Origen's Hexapla, and has nothing but scorn for the scholarly tool produced by the industry of Eusebius's predecessor: 'in juxtaposing texts one next to the other, and in inviting comparative reading, Origen constructed a textual universe that constituted a virtual counter-model to the mouvance of the performative tradition'. ${ }^{14}$ Eusebius's work, however, was even more degenerate than Origen's, relying as it did upon the insight that numbers can symbolically stand in for discrete units of discourse, a technique virtually impossible with oral communication. This, Kelber boldly asserts, represents the "mathematization of texts"15-a phrase that is clearly intended to evoke horror among his readers. Kelber recognizes that the canon tables introduced 'an entirely new approach to reading and understanding the four gospels', by enabling 'comparative thinking across gospel narratives'. This new mode of inquiry, however, came at an unacceptably steep price: the 'numerical logic' gave the 'illusion of a closed system'. Due to its 'artificiality' the system of canon tables 'had no basis in the real life of the gospels nor did they leave any room for social engagement, for participation in the oral-scribal-oral loop, or for compositional involvement in memorial processes' ${ }^{16}$ Kelber's comments on the canon tables are brief but his point is clear enough. He sees them as intrinsically reductive, disconnecting the text of the gospels from oral performance and therefore marking a significant moment in the history of the 'closure' of the biblical text.

The first thing that needs to be said in response to Kelber is that the problem that so exercises him was, in some form, recognized by Eusebius himself. To be sure, Eusebius was not concerned with orality in the way Kelber is, but he did realize that a certain way of presenting the text of the gospels destroyed their organic narrative form, a consequence that he sought to avoid. I refer here to the so-called Diatessaron-Gospel of Ammonius of Alexandria, mentioned by Eusebius in his Letter to Carpianus. Ammonius had created a gospel synopsis, which Eusebius recognized as a powerful reference tool, though he pointed out that it had the unfortunate consequence of making it impossible to read any of the latter three gospels in their normal sequence. ${ }^{17}$ Eusebius, therefore, to put it into Kelber's terms, recognized the 'artificiality' (yet also utility!)

14 Kelber 2010, 126. For a more sympathetic account of Origen's Hexapla, see especially Grafton/Williams 2006, chapter 2.

15 Kelber 2010, 126.

16 Kelber 2010, 126.

17 On the relation of Ammonius and Eusebius, see Crawford 2015, 1-29, which in a revised and expanded version serves as chapter two of Crawford 2019. 
of Ammonius's composition, and his creation of a still more 'artificial' numerical coding system was intended to preserve intact the internal narrative structure of the texts.

\section{Jack Goody on the cognitive impact of writing}

Though Kelber's disparagement of the canon tables is off the mark, there is an element of truth in his argument that can be strengthened by considering the results of anthropological fieldwork. In the latter half of the twentieth century, the British anthropologist Jack Goody spent much of his career studying the impact of literacy upon people's intellectual habits and the social structures they inhabit. One of his consistent arguments, from the beginning to the end of his career, was that writing enables a kind of critical thinking that simply is not possible in a non-literate, purely oral society. I quote here from his 1977 monograph:

\begin{abstract}
Culture, after all, is a series of communicative acts, and differences in the modes of communication are often as important as differences in the mode of production, for they involve developments in the storing, analysis, and creation of human knowledge, as well as the relationships between the individuals involved. The specific proposition is that writing, and more especially alphabetic literacy, made it possible to scrutinise discourse in a different way by giving oral communication a semi-permanent form; this scrutiny favoured the increase in scope of critical activity, and hence of rationality, scepticism, and logic [...] It increased the potentialities of criticism because writing laid out discourse before one's eyes in a different kind of way [...] the human mind was freed to study static 'text' (rather than be limited by participation in the dynamic 'utterance'), a process that enabled man to stand back from his creation and examine it in a more abstract, generalised, and 'rational' way. ${ }^{18}$
\end{abstract}

The two key insights that I want to draw from this passage are first, that writing engages the visual rather than simply the aural sense, and as a result invites the kind of analysis that is only possible with the eyes; and, second, that the act of writing represents a 'decontextualisation' of language from the oral utterance. ${ }^{19}$ The words on the

18 Goody 1977, 37. See the similar comments made in Goody 2000, chapter 8, 'Technologies of the Intellect: Writing and the Written Word'.

19 Goody 1977, 78: 'We have seen that there are two main functions of writing. One is the storage function, that permits communication over time and space, and provides man with a marking, mnemonic and recording device. Clearly this function could also be carried out by other means of storage such as the tape-recording of messages. page, abstracted from a singular moment of oral speech, are now present in semi-permanent form and so open to examination with the eyes. Elsewhere in his book Goody identifies comparative analysis as one such mode of examination that is much more easily done in writing than in an oral process: 'it is certainly easier to perceive contradictions in writing than it is in speech, partly because one can formalise the statements in a syllogistic manner and partly because writing arrests the flow of oral converse so that one can compare side by side utterances that have been made at different times and at different places' ${ }^{20}$ Furthermore, Goody argues that this process of decontextualization that begins with the transfer of oral speech to written text is intensified in certain specific information devices, namely lists, tables, formulas, and recipes, which are even further from oral discourse. The list, for example, 'relies on discontinuity rather than continuity; [...] it can be read in different directions, both sideways and downwards, up and down, as well as left and right; [...] Most importantly it encourages the ordering of the items, by number, by initial sound, by category, etc. And the existence of boundaries, external and internal, brings greater visibility to categories, at the same time as making them more abstract'. ${ }^{21}$

Though Goody's analysis in this book and others depends largely upon anthropological fieldwork in Africa, his description of the cognitive effect of a 'list' aptly captures some of the most important features of the Eusebian canon tables, features that people like ourselves, who are inundated with tables and lists from primary school onwards, are likely to overlook. First of all, the sectioning within each gospel creates chunks of text that are demarcated according to an artificial rationale (i.e., whether they have parallels amongst the other gospels), which abstracts these units of text from the organic narrative flow of each of the four. Next, each passage is assigned a number, by which it can be symbolically represented and more easily manipulated, a process that removes the user still further from the original text. In a final step of decontextualization, these artificially demarcated and

However, the use of aural reproduction would not permit the second function of writing, which shifts language from the aural to the visual domain, and makes possible a different kind of inspection, the re-ordering and refining not only of sentences, but of individual words. Morphemes can be removed from the body of the sentence, the flow of oral discourse, and set aside as isolated units capable not simply of being ordered within a sentence, but of being ordered outside this frame, where they appear in a very different and highly 'abstract' context. I would refer to it as a process of decontextualisation'.

20 Goody 1977, 11-12.

21 Goody 1977, 81. Cf. Goody 2000, 141. 
enumerated chunks of text are sorted into ten highly abstract categories which are entirely unrelated to the original contexts from which they come. The artificiality of this process is thrown into sharper relief if we contrast it with another system of sorting that might have gathered together all of Jesus' parables, or perhaps all of his interactions with women, or statements from the disciples, etc. Such categories would still decontextualize these passages from the four narratives, but they are not nearly as abstract as the ten categories that Eusebius has devised, which have no basis in the text of any single gospel but rely instead on the various relations amongst the four.

This might seem to be belaboring the obvious, but, as I hinted at a moment ago, the fundamental shift that the canon tables represent are one of the most difficult things for people like us to grasp, since the tabular form and citation of text by number are so common in our everyday experience. The ingenuity of Eusebius's system becomes more apparent through consideration of the work of two classicists who have recently studied reading culture among Greek- and Latin-speakers in antiquity. Andrew Riggsby's recent monograph on information technology in the Roman world argues that '[e]ven in their most literary moments, Romans preferred imagining texts (at least potentially) as speech acts'. ${ }^{22}$ This implicit view of text as speech acts, he hypothesizes, accounts for certain striking features of Roman reading culture. For example, among Latin speakers prior to the fourth century, the presentation of numbers or words in a tabular form is 'vanishingly rare', and paratexts, though not completely unknown, were also rare. ${ }^{23} \mathrm{~A}$ further consequence of the imagining of text as speech is that Roman authors have a strong disposition against citing passages of text by any abstract system of reference, such as a book number or line number, and when they do engage in this kind of cross-reference, they typically summarize the text being referred to anyway. In other words, there is a strong Roman norm against [what Riggsby calls] "obligatory cross-reference"', that is, cross-references that require the reader to actually go and look at a second text rather than also summarizing its content. ${ }^{24}$ Reviel Netz has made a similar argument about Greek literature, specifically drawing a contrast between Greek mathematical texts and Greek literary texts, proposing that the near absence of images or illustrations from literary works is due to

22 Riggsby 2019, 8.

23 Riggsby 2019, 6, 8. On Latin paratexts, see also the collected essays in Jansen 2014.

24 Riggsby 2019, 20-22. the similar assumption that written text is simply the encoding of a past moment of oral speech, which serves as the necessary apparatus for reenacting that speech act in a further performance. ${ }^{25}$ Seen against this late antique cultural background, Kelber is right that the canon tables represent a significant step away from the ideal of an oral performance towards a more textual way of thinking about language.

Therefore, up to this point, Goody's conclusions about the cognitive impact of writing in contrast with oral discourse support Kelber's claim that the canon tables are marked by a distinct 'artificiality' since the system 'ha[s] no basis in the real life of the gospels'. The extent of this claim, however, depends upon what one imagines the 'real life of the gospels' to be. Kelber's statement implies that the canon tables are a kind of foreign imposition upon the text of the gospels, and, if one views their essence to be oral performance, that would be true. ${ }^{26}$ However, by Eusebius's day, the gospels had long existed in written form, and their compilation into a fourfold canon made obvious that these four texts bore some relation to one another, even if that relation remained obscure. In light of their already textualized form, a more positive way of describing the effect that the canon tables had upon the four gospels would be to rephrase Goody's argument by saying that they bring greater visibility to the relational categories that were already implicit in the fourfold canon itself. It was, in other words, a process of making explicit that which was already implicit rather than the intrusion of an alien force. ${ }^{27}$ Furthermore, Goody's work suggests that we should see the effect of this process as an opening, rather than a closing of the gospel texts, since decontextualization enables new 'modes of thought'. ${ }^{28}$ As a result of their sorting into artificial categories of relation, passages within the fourfold gospel could now be examined in ways previously impossible such as, for example, investigating

25 Netz 2013, 237-240.

26 Goody likewise acknowledges that putting the oral into written form does bring an end to a certain kind of 'creative development' (Goody 2000, 105).

27 Here I again paraphrase another of Goody's claims, namely that the effect of writing and related information technologies is 'to make the implicit explicit' (Goody 2000, 164).

28 Goody 1977, 81, suggested "we interpret "modes of thought" in terms of the formal cognitive and linguistic operations which this new technology of the intellect opened up'. Cf. Goody 2000, 144: 'So when I use the phrase "technology of the intellect" about writing, I am thinking mainly not about the primary level of physical instrumentation but about the way that writing affects cognitive or intellectual operations, which I take in a wide sense as relating to the understanding of the world in which we live, especially the general methods we use for this'. 
all the content that Matthew shares with Mark and Luke, or that Luke shares with John. This is the sort of comparative analysis that is almost impossible in purely oral discourse, and difficult even with four unmarked texts, but is the primary purpose of the Eusebian apparatus. It is, therefore, precisely the abstract nature of the Eusebian paratext that makes it so powerful as an analytical tool. To illustrate these new possibilities opened up by the canon tables, I turn now to one specific manuscript.

\section{Victor of Capua and Codex Fuldensis}

Victor of Capua was responsible for perhaps the most original and unexpected use of Eusebius's marginal apparatus in the Latin tradition, one that illustrates how the technology devised by the Caesarean historian contained a potential utility that exceeded the immediate purpose of its inventor. Victor was bishop of Capua approximately a century and a half after Jerome had introduced the canon tables into the Latin manuscript tradition, and it seems that by this point they had become a staple of Latin gospel books, as implied by the brief discussions of them found in Cassiodorus and Isidore, who both wrote in the halfcentury or so after Victor. ${ }^{29}$ Victor holds a unique place in the history of the Latin New Testament as a result of his efforts at producing the manuscript known as Codex Fuldensis, noteworthy today as the oldest complete copy of the Latin New Testament in existence. Victor did not copy the manuscript himself but commissioned its production and added a subscription at the end dated 19 April 546 in which he indicated that he had proofread the entire manuscript, followed by a further subscription added on 12 April 547 marking the completion of a second proofread. ${ }^{30}$ Yet the edition of the gospels that Victor included in this copy of the Latin New Testament was, to put it mildly, unusual. ${ }^{31}$ In the preface he wrote for the manuscript he explained how he happened to come across 'a single gospel compiled from the four' (unum ex quattuor euangelium conpositum), which lacked a title. ${ }^{32}$ He there-

29 Cassiodorus, inst. 1.7.2; Isidore, etymol. 6.15.

30 On the dates, see Fischer 1963, 546-548. The dates are given incorrectly in Petersen 1994, 45 n. 33. There are indeed numerous emendations in Victor's hand in the manuscript, including corrections made in the marginal notation for the Eusebian paratext.

31 Another oddity about Codex Fuldensis is that Victor included the apocryphal letter to the Laodiceans amongst the Pauline corpus.

32 The most recent edition of Codex Fuldensis is Ranke 1868. I cite here the preface on pp. 1-3. Translations of the preface are my own fore undertook his own research to discern the possible source of this curious text. Today it is generally agreed that he had somehow stumbled across a Latin copy of Tatian's so-called Diatessaron, and the manuscript that he commissioned is now regarded as one of the most important witnesses to Tatian's composition. ${ }^{33}$ The text typically known as the Diatessaron was created sometime in the late second century by Tatian the Assyrian who combined elements from all four canonical gospels into a single, continuous narrative. ${ }^{34}$ It later exerted a profound influence upon Syriac-speaking Christianity, though Codex Fuldensis is the earliest trace of it to appear in the Latin tradition. ${ }^{35}$

Despite its anonymity and lack of title, Victor was able to deduce the origins of his exemplar by investigating earlier Christian literature, specifically the writings of Eusebius. In the preface he explained that he discovered two prior persons who were said to have produced such a text. First, he noted that in the Letter to Carpianus Eusebius had stated that Ammonius of Alexandria "joined to the Gospel of Matthew extracts from the remaining three gospels and in this way wove the gospel into a single sequence' (matthei euangelio reliquorum trium excerpta iunxisse, ac sic in unam seriem euangelium nexsuisse). ${ }^{36}$ Second, Victor pointed out that Eusebius, in his Ecclesiastical History, had also said that Tatian did something of this sort, producing an unum ex quattuor euangelium. ${ }^{37}$ Since Eusebius had said Ammonius gave priority to Matthew in his 'Diatessaron', and since the version he had before him began with the principia of Luke, ${ }^{38}$ rather than Matthew,

and I must thank Michael Hanaghan for his assistance with several passages. I have chosen to follow the punctuation of the text as presented in Patrologia Latina, LXVIII, which seems to me to be superior to Ranke's punctuation. A new edition of the text is in preparation by Nick Zola. A digitized version of the manuscript can be accessed here: http://fuldig.hs-fulda.de/viewer/image/PPN325289808/1 (last accessed 13/04/2020).

33 Cf. Petersen 1994, 45-51; Houghton 2016, 56-58.

34 On the title of Tatian's work, see Crawford 2013, 362-385, and for a recent collection of studies exploring various aspects of its composition and reception, see Crawford/Zola 2019.

35 On the influence of Fuldensis on the medieval Latin tradition, see especially Schmid 2005.

36 Victor, praef. (Ranke 1868, 1). Victor seems to have misunderstood the nature of Ammonius' text, as noted long ago by Zahn 1881, 31. Ammonius did not make a singular gospel with a continuously running narrative like the text in Codex Fuldensis but instead a gospel synopsis, consisting of parallel passages placed alongside one another, likely in parallel columns.

37 Victor, praef. (Ranke 1868, 1). Cf. Eusebius, HE 4.29.6.

38 Victor, praef. (Ranke 1868, 2). By principia Victor apparently meant the opening portion of Luke's gospel, since Codex Fuldensis begins with Luke 1:1-4 before transitioning to John 1:1-4. 
Victor inferred, by a process of elimination, that he had discovered a copy of Tatian's work.

This recognition, however, presented him with a problem. By the time he was writing, Latin authors were well acquainted with Tatian's reputation as a heretic thanks to Rufinus's translation of Eusebius's Ecclesiastical History, and Victor realized that some of his readers might find it objectionable to use a text composed by such a disreputable person. He admitted that Tatian partook of the error of the Encratites and of Marcion, and that he even 'is said to have applied the hands of impious emendation-or to use a more accurate phrase, the hands of corruption-to the apostolic sayings' (sed et dictis apostolicis manus profanae emendationis, uel (ut dicam uerius) corruptionis dicitur intulisse), referring with the latter phrase to Eusebius's report that Tatian paraphrased the letters of Paul. ${ }^{39}$ Victor thus acknowledged the doubly problematic nature of Tatianic authorship of the text before him: not only might Tatian's heretical theology make his literary creation suspect, but the fact that he is also known to have corrupted the letters of Paul raises the possibility that he might have engaged in illicit textual emendation of the gospels as well. Victor, therefore, had both to justify the use of a work written by a heretic, and to reassure his readers that the unified text of the gospels before them did not differ from that found in a standard four-gospel codex. To answer the first obstacle, Victor pointed out that

et hominum perfidorum (christi dei nostri operante potentia) confessione uel opere, saepe triumphat gloria ueritatis. (nam et daemones christum fatebantur; ...); tatianus quoque, licet profanis inplicatus erroribus, non inutile tamen exhibens studiosis exemplum, hoc euangelium (ut mihi uidetur) sollerti conpaginatione disposuit. ${ }^{40}$

the glory of the truth often triumphs either through confession or deeds, even those of faithless people, thanks to the operation of the power of Christ our God. For even the demons used to confess Christ [...] Likewise Tatian, although entangled in impious errors, nevertheless offers a useful example to the studious as he ordered this gospel with what seems to me to be a skillful arrangement.

39 Victor, praef. (Ranke 1868, 1). On Tatian's editing of the Pauline letters, see Eusebius, hist. eccl. 4.29.6, who interpreted it as an attempt to improve the apostle's style. On Tatian's reputation as a heretic, see most recently Koltun-Fromm 2008, 1-30; Trelenberg 2012, 204-219; Crawford 2016, 542-575.

40 Victor, praef. (Ranke 1868, 1-2).
Hence, Victor reasoned,

uel si iam heresiarces huius editionis auctor exstitit tatianus, uerba domini mei cognoscens, libenter amplector interpretationem..$^{41}$

even if the author of this edition turned out to be the heresiarch Tatian, I recognize the words of my Lord and gladly embrace his exposition.

In other words, if the words the demons spoke about Christ were nevertheless true, so too Tatian's gospel composition should not be rejected simply on the basis of its author's depraved character.

How might then one overcome the second of Victor's obstacles, the possibility that this unum ex quattuor euangelium might contain not only the standard text of the gospels but also, as Victor puts it, Tatian's 'own words' (eius propria) interspersed throughout the sacred text? ${ }^{42}$ Victor realized that Eusebius, the source of his problematic information about Tatian, also provided him with the solution to this difficulty in the form of his canon tables. The entire second half of his preface to Codex Fuldensis is devoted to a discussion of the paratextual apparatus, akin to Jerome's own Novum Opus letter to Pope Damasus that prefaced the Vulgate gospels. Immediately after reviewing the details of Tatian's career and legacy as recounted by Eusebius, Victor then commented:

hoc igitur euangelium, cum absque numeris repperissem, quos ammonius mirabili studio repperit; Eusebius uero caesareae episcopus palestinae, ab eo accipiens exemplum, diligenter excoluit, quibus communiter ab euangelistis dicta uel propria sunt notulis declarata; domino iuuante, studium laboris inpendi, ut memoratos numeros per loca congrua diligenter adfigerem. quodsi dubitatio alicuius uerbi fortasse prouenerit, ex appositis numeris ad plenariam recurrens quilibet euangelii lectionem, an et ibidem ita se sermo habeat de quo ambiguitas prouenerat, incunctanter inueniat, et absque scrupulo studiosi mens secura hoc possit uti uolumine. ${ }^{43}$

41 Victor, praef. (Ranke 1868, 2).

42 Victor, praef. (Ranke 1868, 2). To the great dismay of scholars of the Diatessaron, Codex Fuldensis has a text-type that is solidly Vulgate, in which the peculiar readings introduced by Tatian into his gospel version have been removed in order to domesticate an otherwise dangerously errant text. We do not know whether this clean-up tactic was accomplished by Victor or was already evident in his exemplar, since he makes no comment on it, but the result was a continuous narrative that retained Tatian's sequence of passages but replaced his original wording for that found in the four separate gospels in Jerome's Vulgate version. This is a process commonly known as 'Vulgatization' in Diatessaronic scholarship. Cf. Petersen 1994, 127-129. For one example of this phenomenon in Codex Fuldensis, see Crawford 2016, 273-274.

43 Victor, praef. (Ranke 1868, 2). 
So then, since I had found this gospel without the numbers that Ammonius by extraordinary effort invented-actually, Eusebius, bishop of Caesarea of Palestine, took a model from him and carefully refined [it] with little notations indicating what was said by the evangelists in common or distinctly-with the Lord's assistance I applied my love of work to carefully attaching the aforementioned numbers throughout the appropriate places. Now if perhaps doubt about some word should arise, anyone, by returning from the adjacent numbers to the full reading of the gospel, should immediately find out whether the words also read thus at that very place where the ambiguity had arisen and so, without any anxiety the untroubled mind of the studious should be able to make use of this book.

Victor here places himself in a lineage of scholarly attention to the text of the gospels. Ammonius exerted 'extraordinary effort' to create the numbers for the gospels, ${ }^{44}$ Eusebius 'carefully' refined Ammonius' invention, and now Victor 'carefully' modified the Ammonian-Eusebian system so that it could be used as a guide to the text of Tatian's unum ex quattuor euangelium.

Yet the Eusebian system was designed, as Victor pointed out, to serve as a guide to the distinct and common material across the four separated gospels. What utility could it have for a unified gospel like Tatian's? Victor's rather laconic explanation is perhaps at first ambiguous but upon reflection must mean something like the following. If a reader of Codex Fuldensis is troubled with doubt over whether a particular passage might contain Tatian's 'own words' instead of the inspired text, he or she can easily use the attached numbers to return to 'the full reading of the gospel', which must refer to the equivalent passage in a standard four-gospel codex. Through comparison of the two codices, the reader could then assure him or herself that the versions contain the same text, albeit in different forms, and thus continue using Tatian's version without any 'anxiety'. As Victor said at the end of his preface, 'The inquisitive reader by first inspecting the aforementioned numbers, if he wants, may easily verify what he has encountered by reading from the note of the number' (memoratus numeros prius curiosus lector, si velit, inspiciens, facile, ex nota numeri, reperta comprobet lectione)..$^{45}$ The adapted Eusebian system thus equips the reader to 'verify' the text of this unum ex quattuor euangelium through a decontextualized comparative analysis. Of course, it would have been possible to undertake this task in the absence of

44 Victor's assumption, however, that Ammonius created the numbers found within the canon tables apparatus is misguided. There is no reason to think that he was responsible for the enumeration, which was instead the product of Eusebius's own ingenuity. Cf. Crawford 2019, 86.

45 Victor, praef. (Ranke 1868, 3). the Eusebian apparatus, but because the form of Tatian's text was so different from that of the four separated gospels, finding the relevant passage would have been tedious and time consuming. It was this problem of 'findability' that Victor realized the Eusebian canon tables could help address. By incorporating the system into Codex Fuldensis, he provided its readers with a numerical key that would enable them quickly and easily to locate the corresponding textual material in its usual form in another codex. In other words, Victor has realized that the apparatus can be used not only as a cross-referencing tool within a single manuscript-Eusebius's original intention-but also as a cross-referencing device across separate manuscripts. ${ }^{46}$

Allow me to illustrate what Victor has in mind with a concrete example. One of the episodes that occurs in all four of the canonical gospels, though with variation in each one, is the story of Joseph of Arimathea who received Jesus' body after the crucifixion and prepared it for burial. Since each of the gospels has distinct details in their respective descriptions of Joseph, Tatian had to work with all four sources, incorporating elements from each into his new, single narrative. In Codex Fuldensis the Joseph episode opens capitulum 172 (CLXXII) on fol. 170v, and in the margin next to the start of the paragraph, one reads the following notation:

$\begin{array}{ll}\text { Mt } & \text { CCCXLVIII } \\ & \text { I } \\ \text { Mr } & \text { CCXXVII } \\ \text { Lc } & \text { CCCXXXII } \\ \text { Io } & \text { CCVI }\end{array}$

The 'I' on line two indicates that this is a passage from Eusebius's first Canon, while the other numbers are, of course, the section numbers for the parallel passages in each of the gospels: Mt §348, Mk §227, Lk §332, Jn §206.47 With this information, one could easily turn to each of these passages in the four gospels and compare their version with that in Codex Fuldensis, and thus be assured that Tatian's text is merely a combination of the distinct elements from those four canonical sources, unsullied by any taint of Tatian's heretical emendation.

46 This intended function could only have been realized if Victor could assume that there was available a sufficient number of fourgospel codices equipped with the apparatus, and in this respect he indirectly testifies to the growing prevalence of the system within the Latin manuscript tradition.

47 Cf. Ranke 1868, 157. Note that Ranke's edition contains a mistake here. He lists Mk §CCXXVIII in the margin, adding in an extra ' $\mathrm{I}$ ', while the marginal number for Mark in the digitized version of the manuscript is clearly CCXXVII. 
If we try to imagine how Victor produced his codex, we will gain a better sense of his achievement. We are so accustomed to operating with texts demarcated into numbered sections, that it is difficult for us to appreciate the difficulty facing someone like Victor who had before him nothing more than a continuous, unmarked text representing an intricate harmonization of four sources, not just at the macro level of pericope but at the micro level of individual phrases and words. He must have begun at the start of his codex with its opening passage, and sought to discern from which of the four gospels the passage derived. Then he went to a codex containing the four separate gospels, which was equipped with Eusebius's apparatus, and found the passage therein, on the basis of mere memory and much searching. Once he had found the relevant passage or passages, he then took the section number or numbers and copied them into the margin of his new manuscript, thereby creating a notation in Codex Fuldensis that pointed the reader to the other codex. For the gospels' passion narratives, this process would have been fairly simple, since these sections present so much common material in largely the same sequence. However, each of the gospels contains distinctive material and even that textual content that is common across multiple gospels often occurs in divergent sequences. As an example of the latter type, consider Jesus' statement that a prophet is without honor in his hometown. Mark includes this saying roughly midway through Jesus' ministry as the conclusion to Jesus' rejection at the synagogue in Nazareth (Mark 6:4); Matthew similarly includes the saying in the episode of Jesus' preaching in Nazareth, but unlike Mark places the scene at the conclusion of a long section of parabolic material (Matt 13:57); Luke relocates the saying much earlier in his gospel, at the very outset of Jesus' public ministry (Luke 4:24); finally John inserted the saying as a parenthetical remark at the conclusion to a lengthy episode that is not found in the other gospels (John 4:44). ${ }^{48}$ For passages like these, scattered throughout the gospels, finding and comparing the parallel passages between Tatian's gospel and the four separated gospels would have been a complex and demanding task in the absence of some sort of referencing system. Since Victor already had a copy of the four gospels equipped with Eusebius's apparatus, all that was required of him was to find one of these four passages, and then to use Eusebius's cross-references to track down the others more easily.

48 This specific passage can be found in cap. 79 of Codex Fuldensis (Ranke 1868, 72), adjacent to the marginal notation Mt §142, Mk §51, Lk §21, and Jn §35.
Moreover, there are two further ways Victor modified the Eusebian system so that it better suited the peculiar gospel version found in Codex Fuldensis. First, he inserted an even more granular level of comparative analysis than Eusebius had done by highlighting within each Tatianic passage the specific parts that came from various gospels. An example of this occurs further down the page on fol. 170v, where the next set of Eusebian numbers occur in the margin. Here we read ${ }^{49}$

$\begin{array}{ll}\text { Io } & \text { CCVIII } \\ & \text { I } \\ \mathrm{Mt} & \text { CCCXLVIII } \\ \mathrm{Mr} & \text { CCXXVIII } \\ \mathrm{Lc} & \text { CCCXXXIII }\end{array}$

The red 'I' in line two denotes that this is again a Canon I passage that occurs in all four gospels, though with some variation. In the text to the right of this marginal notation, where the corresponding section of Tatian's version begins, the scribe has written the abbreviations for all four gospels into the line before the start of the section, telling the reader that what follows comes from all four gospels (acceperunt ergo corpus ihesu ...). However, two lines down, once again in the left margin, one reads a small red 'Io', denoting that the next bit of text that follows is distinctive to John's account of Joseph's burial of Jesus (et ligauerunt eum ...), and three lines below that again a red 'Io' is in the margin, since this bit of text also is unique to John (erat autem in loco ...). Finally, on the penultimate line on the page, after the first word one sees the symbols 'Lc Io' in red, indicating that the text that follows is a detail that occurs in both Luke and John. Eusebius had rightly presented all four of the accounts of Jesus' burial as parallel to one another, but Victor has realized, probably through a close comparison of Tatian's version and the separated gospels, that differences between the passages remain, and he has meticulously incorporated a fine-grained system of analysis that operates within the framework of the Eusebian paratext to indicate to the reader where these differences and commonalities lie.

The second way Victor adapted the Eusebian system was by adding a further level of navigational complexity within the modified version of Eusebius's prefatory tables that he included at the start of his new codex. He kept the numbers for the parallel passages that Eusebius had orig-

49 Victor seemingly made a mistake here, listing Mt §CCCXLVIII instead of Mt §CCCXLVIIII. The mistake is repeated within the canon tables at the start of the codex (see below), so Victor's system is at least internally consistent even if it diverges from Eusebius's original by duplicating Mt $\S 348$ and omitting Mt $\S 349$. 
inally included in each canon, but added in the capitula numbers within which each of the parallel passages occur in Codex Fuldensis. So, for example, within Canon I on fol. 6r, under capitulo CLXXII are found the numbers for the passages from the separate gospels that pertain to Joseph of Arimathea: ${ }^{50}$

\section{Mt §CCCXLVIII Mk §CCXXVII Lk §CCCXXXII Jn §CCVI} Mt §CCCXLVIII Mk §CCXXVIII Lk §CCCXXXIII Jn §CCVIII

By inserting the capitulum number for this episode, which is unique to the narrative of Codex Fuldensis, Victor has made it possible for the reader to start from any given passage within an edition of the separate gospels and then to find that passage within Tatian's version. So, if one were reading the Gospel of Matthew in a normal codex, one could note down the section and canon number for the episode about Joseph of Arimathea, find the section number in the Matthew column of Victor's modified canon I, and then turn to the capitulum under which it appears to read Tatian's combined version of the scene. This insertion of the capitula numbers accounts for one of the peculiarities about the canons in Codex Fuldensis. In Eusebius's original design the parallels within each of the canons are arranged by placing the numerals in the first column in ascending order, based on the Gospel of Matthew in the first seven canons, Luke in canons eight and nine, and each of the respective gospels in canon ten. However, in Codex Fuldensis, the numbers in the first column do not always go in ascending order, but instead often jump around. This variance is due to the fact that Victor has reordered the parallels within each of the canons so that they instead follow the sequence of capitula within each canon, with the result that the capitula numbers always proceed in ascending order. In this respect he has subordinated Eusebius's referencing system to the sequence of capitula unique to Codex Fuldensis, but ensured that the Eusebian paratext is still a functional navigational device across multiple codices. Using Victor's modified Eusebian apparatus, one could go back and forth as desired between Tatian's version and a version of the separate gospels, regardless of which text one began with.

With these additions to Eusebius's original system, Victor managed to create a book more paratextually complex than any that had previously existed in the Latin tradition. No other text known to us had ever been pro-

50 Cf. Ranke 1868, 7. Ranke's edition again contains a mistake here. He lists Mk §CCXVII in the first line though the manuscript clearly reads $\mathrm{Mk} \S \mathrm{CCXXVII}$. duced in a form accompanied by a continuously running marginal set of references to another text or texts. This is around the same time that the catena form emerged in the Greek tradition, and there is a certain similarity between the catena format and Victor's codex, in that both exploit marginal space to incorporate paratextual material related to the central text on the page. However, in the catena form, the scribe copies the relevant secondary text directly into the margin, whereas Victor has merely copied the numerical references for those secondary texts. His system therefore is more abstract and requires more effort on the part of the reader who is expected to go and look up the passages in a separate codex. It is, therefore, the sort of 'obligatory cross-reference' that Riggsby argues is exceedingly rare in Latin sources prior to the fourth century. There is a further aspect of the reasoning process implied by Victor's creation that is also remarkably original but easy to miss. In order to adapt the Eusebian system of canon tables to Codex Fuldensis, he had to begin with each passage in the Diatessaron and then identify the sources that Tatian used in composing it. This again distinguishes Victor's paratextual apparatus from the catena form, since in the latter the textual material copied into the margin is not a source for the central text on the page but is rather a commentary upon it. In contrast, rather than providing room for a further text derivative of the main text, Victor pushed his readers in the opposite direction by forcing upon them questions about the origin of the main text. In essence what he undertook was a massive exercise in source criticism, and what he produced for posterity was an annotated version of Tatian's unum ex quattuor euangelium showing the sources employed at each stage of the narrative. This is once more a form of reasoning about texts that seems obvious to us, but it was stunningly novel in the sixth century. No one, for example, had ever applied this approach to the four canonical gospels themselves, ${ }^{51}$ and it would be centuries before anyone would do so. It did not occur to Victor to ask what sources the four evangelists might themselves have used, but he did consider Tatian's use of his sources, and it is only a small step from his undertaking to the source critical analysis of the four gospels, which serves as one of the pillars of modern New Testament scholarship.

51 Though some have claimed that Augustine pioneered this approach in his highly influential treatise De consensu euangelistarum, see the rebuttal of this notion in de Jonge 1992, 2409-2417. 


\section{Conclusion}

The mode of reading encouraged by the marginal apparatus in Codex Fuldensis represents a marked shift away from the imagined oral performance of the scroll that I discussed earlier, since Victor's marginal apparatus assumes that the reader's interaction with the codex will (at least potentially) be constantly interrupted by his or her perusal of a second codex in order to compare multiple texts sideby-side. To this degree, Codex Fuldensis supports Kelber's argument that the canon tables enforce a certain kind of closure, by distancing the text of the gospels from a (possibly imaginary?) original oral performance out of which they emerged. However, Victor's codex likewise reveals the profound potential that the canon tables had to open up the text of the gospels to new modes of inquiry, encouraging the sort of critical thinking and comparative analysis that Goody argues are key features of written discourse in contrast to the oral. Naturally Eusebius never imagined using his system of canon tables as a cross-referencing system within another text like the Diatessaron, but his paratext was the indispensible tool that made possible Victor's fine-grained analysis of Tatian's gospel. What Eusebius handed on to Victor were two innovations: first a mapping of parallel passages amongst the four gospels; and second a numerical citation system for more easily manipulating and referencing those passages. The first of these Eusebian contributions allowed Victor to compare the separate gospels with Tatian's unified version and thereby to identify the various elements that Tatian had drawn upon, ${ }^{52}$ while the second enabled him

52 My argument here raises another question that to my knowledge has not yet been pursued in the scholarly literature on Codex Fuldensis and the Diatessaron, namely the degree to which the canon tables led Victor to modify his exemplar. Some parallels amongst the gospels are of course obvious while others are more open to debate and assume some interpretation on the part of the reader. Hence, Tatian's Diatessaron and Eusebius's canon tables would certainly not have been a perfect match in terms of how they handled passages from the gospels. For example, Eusebius presented Jesus' anointing by a woman as a passage in Canon I common to all four gospels (Mt 26:611; Mk 14:3-7; Lk 7:36-50; Jn 12:2-8 = Mt §276; Mk §158; Lk §74; Jn §98). Tatian, however, seems to have separated the Lukan account from the other three and so made a double anointing of Jesus (see Ephrem, Comm. Diat. 10.8-10; 17.11-13). Since Fuldensis goes back to Tatian's Diatessaron one would expect it to have two separate anointings but in fact it records only one (cap. 138-139; Ranke 1868, 123-124). If Victor's exemplar in fact had two anointings, he may have been led to combine them under the influence of Eusebius's canon tables. Even though there is no doubt that Codex Fuldensis is a witness to the Diatessaron, it has long been known that it diverges from other witnesses, most notably Ephrem and the Arabic Diatessaron. Perhaps investigation of Victor's use of the canon tables could account for at least some of these to provide the readers of Codex Fuldensis with a system for following in his footsteps and performing the same task for themselves. Victor's modified canon tables are, therefore, an example of Goody's claim that 'tools create further tools', ${ }^{53}$ since the Capuan bishop exploited the unrecognized potential inherent to Eusebius's invention by applying his information technology to a new problem. The continuity between these two endeavors lies in the assumptions that texts can be referenced by number and should be placed alongside other texts for the purpose of comparative analysis, and in these respects Codex Fuldensis indicates that this mode of reading, which was foreign to the first century CE, was becoming a standard feature of the emerging book culture of the late antique and medieval periods. ${ }^{54}$ Moreover, it is an approach to texts that is the forerunner to the scholarly methods that all of us today regularly employ.

discrepancies. I am grateful to Ian Mills for drawing my attention to this example of how Jesus' anointing is handled in Fuldensis in contrast to Ephrem's commentary on Tatian's gospel. He discusses this example in his chapter 'The Wrong Harmony: Against the Diatessaronic Character of the Dura Parchment', in Crawford/Zola 2019.

53 Goody 2000, 137: 'The tools of literates provide their societies with technologies of a cognitive kind, technologies that are themselves tools, for tools create further tools'.

54 For one exploration of how the late antique shifts that are evident in Eusebius's works were carried forward and developed further in the medieval period, see Carruthers 2008, who discusses canon tables on pp. 118-121. 


\section{References}

Butler, Shane (2014), 'Cicero's Capita', in Laura Jansen (ed.), The Roman Paratext: Frame, Texts, Readers, Cambridge: Cambridge University Press, 73-111.

Carruthers, Mary (2008), The Book of Memory: A Study of Memory in Medieval Culture, Cambridge: Cambridge University Press.

Coogan, Jeremiah (2017), 'Mapping the Fourfold Gospel: Textual Geography in the Eusebian Apparatus', Journal of Early Christian Studies, 25, 337-357.

Crawford, Matthew R. (2013), 'Diatessaron, a Misnomer? The Evidence From Ephrem's Commentary', Early Christianity, 4, 362-385.

Crawford, Matthew R. (2015), 'Ammonius of Alexandria, Eusebius of Caesarea and the Origins of Gospels Scholarship', New Testament Studies, 61, 1-29.

Crawford, Matthew R. (2016), 'The Problemata of Tatian: Recovering the Fragments of a Second-Century Christian Intellectual', The Journal of Theological Studies, NS 67, 542-575.

Crawford, Matthew R. (2019), The Eusebian Canon Tables: Ordering Textual Knowledge in Late Antiquity, Oxford Early Christian Studies, Oxford: Oxford University Press.

Crawford, Matthew R. and Nicholas J. Zola (eds) (2019), The Gospel of Tatian: Exploring the Nature and Text of the Diatessaron, The Reception of Jesus in the First Three Centuries, London: T\&T Clark.

Fischer, Bonifatius (1963), 'Bibelausgaben des frühen Mittelalters' in La Bibbia nell'alto Medioevo, Spoleto: Presso la Sede del Centro, 546-548.

Goody, Jack (1977), The Domestication of the Savage Mind, Cambridge: Cambridge University Press.

Goody, Jack (2000), The Power of the Written Tradition, Washington, D.C.: Smithsonian Institution Press.

Grafton, Anthony and Megan Hale Williams (2006), Christianity and the Transformation of the Book: Origen, Eusebius, and the Library of Caesarea, Cambridge, MA: Belknap Press of Harvard University Press.

Houghton, H. A. G. (2016), The Latin New Testament: A Guide to Its Early History, Texts, and Manuscripts, Oxford: Oxford University Press.

Jansen, Laura (ed.) (2014), The Roman Paratext: Frame, Texts, Readers, Cambridge: Cambridge University Press.

de Jonge, H. J. (1992), 'Augustine on the Interrelations of the Gospels', in F. Van Segbroeck (ed.), The Four Gospels (Fs Frans Neirynck), Leuven: Leuven University Press, 2409-2417.
Kelber, Werner H. (2010), 'The History of the Closure of Biblical Texts', Oral Tradition, 25, 115-140.

Koltun-Fromm, Naomi (2008), 'Re-Imagining Tatian: The Damaging Effects of Polemical Rhetoric', Journal of Early Christian Studies, 16, 1-30.

McArthur, Harvey K. (1965), 'Eusebian Sections and Canons', Catholic Biblical Quarterly, 27, 250-256.

Mullins, Elizabeth (2014), 'The Eusebian Canon Tables and Hiberno-Latin Exegesis: The Case of Vienna, Österreichische Nationalbibliothek, lat. 940', Sacris Erudiri, 53, 323-344.

Mullins, Elizabeth (2001), 'The Insular Reception of the Eusebian Canon Tables: Exegesis and Iconography', Diss., University College Cork.

Netz, Reviel (2013), 'Authorial Presence in the Ancient Exact Sciences', in Markus Asper (ed.), Writing Science: Medical and Mathematical Authorship in Ancient Greece, Berlin: De Gruyter, 237-240.

Nordenfalk, Carl (1984), 'The Eusebian Canon-Tables: Some Textual Problems', The Journal of Theological Studies, NS 35/1, 96-104.

O'Loughlin, Thomas (2010), 'Harmonizing the Truth: Eusebius and the Problem of the Four Gospels', Traditio, 65, 1-29.

O'Loughlin, Thomas (2017), 'The Eusebian Apparatus in the Lindisfarne Gospels: Ailerán's Kanon Euangeliorum as a Lens for Its Appreciation', in Richard Gameson (ed.), The Lindisfarne Gospels: New Perspectives, Library of the Written World, 57, The Manuscript World, 9, Leiden, Boston: Brill, 96-111.

Ong, Walter J. (1992), 'Technology Outside Us and Inside Us', in Thomas J. Farrell and Paul A. Soukup (ed.), Faith and Contexts, I, Atlanta: Scholars Press, 115-140.

Petersen, William L. (1994), Tatian's Diatessaron: Its Creation, Dissemination, Significance, and History in Scholarship, Leiden: E.J. Brill.

Ranke, E. (1868), Codex Fuldensis, Marburg, Leipzig: Elwert.

Riggsby, Andrew M. (2019), Mosaics of Knowledge: Representing Information in the Roman World, Classical Culture and Society, Oxford: Oxford University Press.

Schmid, Ulrich (2005), Unum ex quattuor: Eine Geschichte der lateinischen Tatianüberlieferung, Freiburg im Breisgau: Herder.

Trelenberg, Jörg (2012), Tatianos. Oratio ad Graecos. Rede an die Griechen, Tübingen: Mohr Siebeck.

Wallraff, Martin (2013), Kodex und Kanon: Das Buch im frühen Christentum, Berlin: De Gruyter.

Zahn, Theodor (1881), Tatian's Diatessaron, Erlangen: Deichert. 
